«Системні технології» 2 (127) 2020 «System technologies»

DOI 10.34185/1562-9945-2-127-2020-03

УДК 621.226

І.А. Мазур, Д.О. Шелудько, М.І. Петров

\title{
ДОСЛІДЖЕННЯ ДИНАМІЧНИХ ПРОЦЕСІВ У ГІДРОСИСТЕМІ МЕХАНІЗМУ ЗАТИСКАННЯ ШТАБИ ДВОКОНУСНОГО РОЗМОТУВАЧА РУЛОНІВ ТЕЗА 159-529
}

Анотація. Робота присвячена дослідженню динамічних навантажень, що виникають у гідросистемі механізму затискання штаби двоконусного розмотувача рулонів TE3A 159529. Досвід експлуатації двоконусного розмотувача показав, що одним з його недоліків $\epsilon$ незадовільна робота гідросистеми затискання штаби, у якій спостерігаються підвищенні динамічні навантаження.

Запропоновано математичну модель дослідження динамічних процесів у гідросистемі затискання штаби з урахуванням хвильових властивостей довгих гідромагістралей. $B$ ході реалізації математичної моделі у програмному середовищі Simulink MATLAB виконано дослідження режимів роботи гідросистеми механізму затискання штаби. У результаті дослідження показано, що у гідросистемі механізму затискання штаби двоконусного розмотувача виникають динамічні навантаження на при кінці зворотного ходу. 3 метою зниження динамічних навантажень, запропоновано порядок роботи гідророзподільників 3 часом спрацьовування у 0,16 сек. Це дозволяє суттєво знизити динамічні навантаження у гідросистемі механізму затискання штаби за рахунок зниження швидкості переміщення гідроциліндрів на при кінці зворотного ходу каретки.

Ключові слова: розмотувач двоконусний, гідросистема, тиск, зусилля, гідророзподільник, час спрацьовування, навантаження динамічні, прочеси перехідні.

Постановка проблеми. В останні роки особливе значення набула модернізація існуючого устаткування трубоелектрозварювального агрегату (ТЕЗА) 159-529 з метою підвищення одиничної продуктивності агрегатів, зниження витрат на допоміжні операції по підготовці штабової заготівлі до формування труби за рахунок раціональної конструкції механізмів і підвищення надійності їх вузлів. При цьому велика увага приділяється дослідженню питань, які спрямовані на поліпшення динамічних характеристик гідравлічних систем агрегату та зниження навантажень в несталих режимах роботи.

(C) Мазур I.А., Шелудько Д.О., Петров М.I., 2020 
«Системні технології» 2 (127) 2020 «System technologies»

Двохконусний розмотувач виконує перші операції підготовки рулону штаби до розмотування в потоці ТЕЗА 159-529, робота якого суттєво впливає на роботу всього агрегату в цілому. Досвід експлуатації двоконусного розмотувача показав, що одним з основних його недоліків є низька надійність та незадовільна робота гідросистеми механізму затискання рулону штаби. При цьому, у гідросистемі затискання рулону штаби спостерігаються підвищенні динамічні навантаження, які призводять до виходу з ладу вузлів та елементів гідросистеми. В гідросистемі застосовуються золотникові гідророзподільники з електрогідравлічним керуванням, час спрацьовування котрих складає 0,32 с та практично не підлягають регулюванню. Окрім цього, компоновка гідросистеми затискання рулону штаби виконана з конструктивних та технологічних міркувань, без урахування впливу довжин трубопроводів на характер динамічних процесів у гідросистемі.

Аналіз останніх досліджень і публікацій. Для оцінки якості роботи гідросистеми двоконусного розмотувача рулонів ТЕЗА 159 - 529 в процесі проектування повинна бути забезпечена можливість визначення впливу компонувальних рішень і конструктивних параметрів гідроелементів, швидкохідність, надійність і якість роботи. Надалі при експлуатації і модернізації двохконусного розмотувача рулонів також виникає необхідність провести цілий ряд уточнюючих розрахунків.

Якщо гідросистема містить довгі магістралі (що характерно для двоконусного розмотувача з насосним приводом), то при аналізі перехідних процесів необхідно враховувати хвильові явища. Критерієм для необхідності обліку розподілених параметрів є співвідношення між характерним часом збурення і часом пробігу акустичною хвилею довжини магістралі [1]. Якщо ці характерні часи сумірні, то хвильові явища необхідно враховувати.

Рівняння гідромеханіки, що описують одномірний нестаціонарний рух в’язкої рідини, є квазілінійними рівняннями гіперболічного типу, для яких є багато способів вирішення. Зокрема, в класичної роботі М.Є.Жуковського [2] використовувався метод Д’Аламбера, що дає наочну картину поширення ударної хвилі по довжині магістралі. 
«Системні технології» 2 (127) 2020 «System technologies»

Ефективний спосіб вирішення хвильового рівняння, розвинений Л.М.Тарко [3], полягає в використанні операційного методу. При цьому рішення рівнянь в приватних похідних зводиться до алгебраїчних операцій над функціями, що визначають характер впливу збурення.

Більш широкими можливостями володіє кінцево-різницеві методи перетворення рівнянь в приватних похідних в систему звичайних диференціальних рівнянь. Моделювання на АОМ гідравлічних пристроїв 3 урахуванням хвильових процесів в трубопроводі розроблено С.Н.Кожевніковим [5]. Питання раціональної побудови математичної моделі при дослідженні за допомогою ЕОМ хвильових процесів в гідросистемі, що складається 3 джерела живлення (насоса 3 постійною подачею робочої рідини), довгого нерозгалуженого трубопроводу і силового гідроциліндра, розглянуті в роботі I.А.Немеровського [5] та у роботах Ж.П.Дусанюк [6-8].

Мета дослідження. Метою роботи є розробка заходів по зниженню динамічних навантажень в існуючій гідросистемі механізму затискання штаби у двоконусному розмотувачі ТЕЗА 159-529 з мінімальними капітальними вкладеннями. У відповідності з поставленою метою вирішені наступні завдання: розроблена математична модель дослідження динамічних процесів у гідросистемі механізму затискання; виконані теоретичні дослідження режимів роботи гідросистеми у періоди розгону та гальмування; рекомендовані раціональні режими роботи гідросистеми.

Викладення основного матеріалу. На підставі аналізу математичних моделей, застосовуваних в практиці динамічних розрахунків реальних гідросистем [1-8], можна зробити висновок, що в якості математичної моделі, яка враховує особливості конструкції і роботи гідросистеми затискання штаби двоконусного розмотувача ТЕЗА 159-529, доцільно використовувати систему диференціальних рівнянь в приватних похідних 3 нелінійними і нестаціонарними коефіцієнтами, перетвореними кінцево-різницевим методом в систему звичайних диференціальних рівнянь з граничними умовами, описаними алгебраїчними рівняннями. Це дає можливість створення базової динамічної моделі, яка дозволяє з високою достовірністю аналізувати поведінку гідросистеми механізму за- 
«Системні технології» 2 (127) 2020 «System technologies»

тискання штаби двоконусного розмотувача рулонів, яка піддається впливу різного характеру в широкому діапазоні режимних параметрів.

Розглянемо розрахункову схему гідросистеми механізму затискання штаби двоконусного розмотувача ТЕЗА 159 - 529 з насосним приводом, котра наведена на рис. 1. Увесь цикл роботи гідросистеми затискання рулону двохконусного розмотувача складається з двох фаз: робочого ходу та зворотного ходу, для кожного з яких характерна своя структура гідромеханічної системи.

При складанні математичного опису процесів, які протикають у гідросистемі механізму затискання штаби, за основу було взято методичну базу створену С.М.Кожевніковим у роботі [4], та у подальшому розвинена А.М.Іоффе, О.М.Кукушкіним, М.В.Міхайловським та I.А.Мазуром у роботах [9, 10, 11]. При створені математичного опису процесів, які протикають у гідросистемі були прийняті наступні припущення:

- тиск робочої рідини створений насосом постійний;

- втрати рідини у гідросистемі механізму затискання штаби двоконусного розмотувача відсутні;

- наведений модуль пружності гідромагістралей не залежить від тиску та температури робочої рідини.

Математична модель довгої гідромагістралі як системи з розподіленими параметрами, для несталого руху реальної пружної рідини, описується диференційними рівняннями в приватних похідних [2, 12]:

$$
\begin{aligned}
& \frac{\partial \mathrm{p}}{\partial \mathrm{x}}=-\rho \cdot\left(\frac{\partial \mathrm{v}}{\partial \mathrm{t}}+\frac{\lambda}{2 \cdot \mathrm{d}} \cdot|\mathrm{v}| \cdot \mathrm{v}\right) ; \\
& \frac{\partial \mathrm{p}}{\partial \mathrm{t}}=-\rho \cdot \mathrm{c} \cdot \frac{\partial \mathrm{v}}{\partial \mathrm{x}}
\end{aligned}
$$

де $\mathrm{p}$-тиск рідини у гідромагістралі; v-швидкість рідини у гідромагістралі; $\lambda, \mathrm{d}$-коефіцієнт гідравлічного опору та діаметр гідромагістралі; $\mathrm{x}$, t -відповідно координата перетину гідромагістралі та час; $\rho$-щільність робочої рідини; с-швидкість розповсюдження пружної хвилі у гідромагістралі та визначається з вираження:

$$
c=\sqrt{E / \rho} .
$$


«Системні технології» 2 (127) 2020 «System technologies»

Тут Е-усереднений модуль об’ємної пружності рідини у гідромагістралі визначається $з$ вираження [10]:

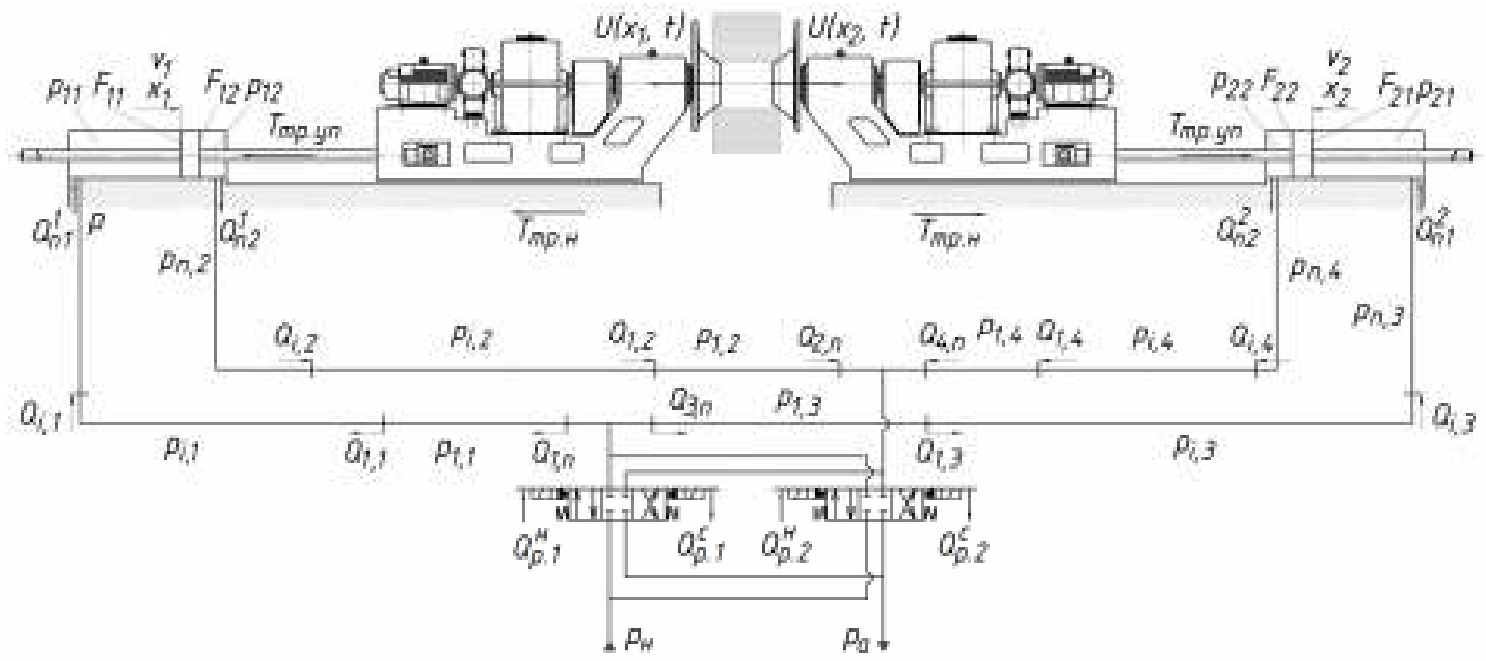

Рисунок 1 - Розрахункова схема гідросистеми механізму затискання штаби двоконусного розмотувача

$$
E=\left(\frac{1}{E_{p}}+\frac{d}{\delta \cdot E_{T}}\right)^{-1} .
$$

Тут $\mathrm{E}_{\mathrm{p}}, \mathrm{E}_{\mathrm{T}}$-модуль пружності рідини та матеріалу трубопроводу; $\mathrm{d}$ та $\delta$-діаметр та товщина стінки трубопроводу.

Для рішення системи (1) в математичній моделі використовується кінцево-різницевий метод перетворення рівнянь в приватних похідних в систему звичайних диференційних рівнянь. Рівняння (1), перетворене таким чином, запишеться для і-тої ділянки ј-тої гідромагістралі у вигляді:

$$
\begin{aligned}
& \frac{d v_{i, j}}{d t}=\frac{p_{i-1, j}-p_{i, j}}{\rho \cdot k_{j}}-\frac{\xi_{i, j}}{2 \cdot k_{j}} \cdot\left|v_{i, j}\right| \cdot v_{i, j} ; \\
& \frac{d p_{i, j}}{d t}=\frac{E_{j}}{k_{j}} \cdot\left(v_{i, j}-v_{i+1, j}\right),
\end{aligned}
$$

де i , j-номер ділянки та індекс гідромагістралі; $\xi_{\mathrm{i}, \mathrm{j}}$-гідравлічний опір iтої ділянки j-тої гідромагістралі; $\mathrm{E}_{\mathrm{j}}$-приведений модуль пружності для 
«Системні технології» 2 (127) 2020 «System technologies»

j-тої гідромагістралі; $\mathrm{k}_{\mathrm{j}}$-шаг дискретизації, який визначається 3 вираження: $\mathrm{k}_{\mathrm{j}}=\mathrm{L}_{\mathrm{j}} / \mathrm{n}_{\mathrm{j}} \mathrm{L}_{\mathrm{j}}$ та $\mathrm{n}_{\mathrm{j}}$-довжина та число ділянок розбиття $\mathrm{j}$-тої гідромагістралі.

Швидкість руху робочої рідини в і-тій ділянці ј-тої гідромагістралі може бути виражена у вигляді:

$$
\mathrm{Q}_{\mathrm{i}, \mathrm{j}}=\mathrm{v}_{\mathrm{i}, \mathrm{j}} \cdot \mathrm{f}_{\mathrm{j}}
$$

де $\mathrm{f}_{\mathrm{j}}$-площа поперечного перерізу j-тої гідромагістралі.

Підставив (3) у (2) та, зробивши перетворення, отримаємо математичну модель гідромагістралі з розподіленими параметрами:

$$
\begin{aligned}
& \frac{d Q_{i, j}}{d t}=\frac{f_{j} \cdot\left(p_{i-1, j}-p_{i, j}\right)}{\rho \cdot k_{j}}-\frac{\xi_{i, j}}{2 \cdot k_{j} \cdot f_{j}} \cdot\left|Q_{i, j}\right| \cdot Q_{i, j} ; \\
& \frac{d p_{i, j}}{d t}=\frac{E_{j}}{k_{j} \cdot f_{j}} \cdot\left(Q_{i, j}-Q_{i+1, j}\right),
\end{aligned}
$$

Для ефективного врахування хвильових властивостей окремих гідромагістралей у моделі передбачений вибір раціонального шагу дискретизації на основі аналізу динамічної реакції гідромагістралі на вплив збурення, характерний для даного гідроприводу. В якості таких впливів збурення в умовах насосного привода найчастіше за все виступають практично миттєве спрацьовування керуючих елементів та раптова зупинка робочого органу на при кінці його руху. Таким чином, для кожної $з$ гідромагістралей було взято раціональне число ділянок розбиття $\mathrm{k}_{\mathrm{j}}$, що забезпечує задану точність моделі.

Умовою спрягання двох суміжних ділянок є рівняння витрат на їх межі, тобто: $\mathrm{Q}_{\mathrm{i}, \mathrm{j}}=\mathrm{Q}_{\mathrm{i}-1, \mathrm{j}}=\mathrm{Q}_{\mathrm{i}-2, \mathrm{j}}$.

Зміна тиску у відповідних порожнинах поршневих гідроциліндрів описується диференційними рівняннями: 
«Системні технології» 2 (127) 2020 «System technologies»

$$
\begin{aligned}
& \frac{\mathrm{dp}_{11}}{\mathrm{dt}}=\frac{\mathrm{E}_{\mathrm{p}}}{\mathrm{V}_{11}^{0}+\mathrm{x}_{1} \cdot \mathrm{F}_{11}} \cdot\left(\mathrm{Q}_{\Pi 1}^{1}-\mathrm{F}_{11} \cdot \frac{\mathrm{dx}}{\mathrm{dt}}\right) ; \\
& \frac{\mathrm{dp}_{12}}{\mathrm{dt}}=\frac{\mathrm{E}_{\mathrm{p}}}{\mathrm{V}_{12}^{0}-\mathrm{x}_{1} \cdot \mathrm{F}_{12}} \cdot\left(\mathrm{F}_{12} \cdot \frac{\mathrm{dx}_{1}}{\mathrm{dt}}-\mathrm{Q}_{\Pi 2}^{1}\right) ; \\
& \frac{\mathrm{dp}_{21}}{\mathrm{dt}}=\frac{\mathrm{E}_{\mathrm{p}}}{\mathrm{V}_{21}^{0}+\mathrm{x}_{2} \cdot \mathrm{F}_{21}} \cdot\left(\mathrm{Q}_{\Pi 1}^{2}-\mathrm{F}_{21} \cdot \frac{\mathrm{dx}_{2}}{\mathrm{dt}}\right) ; \\
& \frac{\mathrm{dp}_{22}}{\mathrm{dt}}=\frac{\mathrm{E}_{\mathrm{p}}}{\mathrm{V}_{22}^{0}-\mathrm{x}_{2} \cdot \mathrm{F}_{22}} \cdot\left(\mathrm{F}_{22} \cdot \frac{\mathrm{dx_{2 }}}{\mathrm{dt}}-\mathrm{Q}_{\Pi 2}^{2}\right) .
\end{aligned}
$$

де $\mathrm{p}_{11}, \mathrm{p}_{12}, \mathrm{p}_{21} \mathrm{i} \mathrm{p}_{22}$-тиск в відповідних порожнинах гідроциліндрів; $\mathrm{F}_{11}, \mathrm{~F}_{12}, \mathrm{~F}_{21} \mathrm{i} \mathrm{F}_{22}$-робоча площа поршнів гідроциліндрів у відповідних порожнинах; $\mathrm{V}_{11}^{0}, \mathrm{~V}_{12}^{0}, \mathrm{~V}_{21}^{0}$ i $\mathrm{V}_{22}^{0}$-початковий об'єм відповідних порожнин гідроциліндрів; $Q_{\Pi 1}^{1}, Q_{\Pi 2}^{1}, Q_{\Pi 1}^{2}$ і $Q_{\Pi 2}^{2}$-витрата робочої рідини в відповідних порожнинах гідроциліндрів; $\mathrm{x}_{1} \mathrm{i} \mathrm{x}_{2}$-координата положення робочого органу гідроциліндрів.

Рух робочого органу механізму затискання штаби двоконусного розмотувача описується однорідними диференційними рівняннями другого порядку:

$$
\begin{aligned}
& \mathrm{m}_{1} \cdot \frac{\mathrm{d}^{2} \mathrm{x}_{1}}{\mathrm{dt}^{2}}+\mathrm{h} \cdot\left(\frac{\mathrm{dx_{1 }}}{\mathrm{dt}}\right)+\mathrm{U}\left(\mathrm{x}_{1}, \mathrm{t}\right)+\mathrm{T}_{\text {тр.н }} \cdot \operatorname{sign}\left(\frac{\mathrm{dx}_{1}}{\mathrm{dt}}\right)+ \\
& +\mathrm{T}_{\text {тр.уп }} \cdot \operatorname{sign}\left(\frac{\mathrm{dx}_{1}}{\mathrm{dt}}\right)-\mathrm{p}_{11} \cdot \mathrm{F}_{11}+\mathrm{p}_{12} \cdot \mathrm{F}_{12}=0 ; \\
& \mathrm{m}_{2} \cdot \frac{\mathrm{d}^{2} \mathrm{x}_{2}}{\mathrm{dt}^{2}}+\mathrm{h} \cdot\left(\frac{\mathrm{dx_{2 }}}{\mathrm{dt}}\right)+\mathrm{U}\left(\mathrm{x}_{2}, \mathrm{t}\right)+\mathrm{T}_{\text {тр.н }} \cdot \operatorname{sign}\left(\frac{\mathrm{dx}}{\mathrm{dt}}\right)+ \\
& +\mathrm{T}_{\text {тр.уп }} \cdot \operatorname{sign}\left(\frac{\mathrm{dx}}{\mathrm{dt}}\right)-\mathrm{p}_{21} \cdot \mathrm{F}_{21}+\mathrm{p}_{22} \cdot \mathrm{F}_{22}=0 .
\end{aligned}
$$

де $\mathrm{m}_{1}, \mathrm{~m}_{2} \mathrm{i} \mathrm{x}_{1}, \mathrm{x}_{2}$-маса та переміщення рухомих частин відповідного робочого органу; $h, \mathrm{U}\left(\mathrm{x}_{1}, \mathrm{t}\right) \mathrm{i} \mathrm{U}\left(\mathrm{x}_{2}, \mathrm{t}\right)$-коефіцієнт в'язкого тертя та навантаження на відповідний робочий орган; $\mathrm{T}_{\text {тр.н }} \mathrm{i} \mathrm{T}_{\text {тр.уп }}$-сила тертя в напрямних каретки та в ущільненнях. 
«Системні технології» 2 (127) 2020 «System technologies»

Граничними умовами для системи рівнянь (2), (4)-(6) є вираження, що являють собою витратно-напірні характеристики відповідних керуючих пристроїв [13]:

$$
\begin{aligned}
& \mathrm{Q}_{\mathrm{p} .1}^{\mathrm{i}}=\mu_{\mathrm{p} .1}^{\mathrm{i}} \cdot \mathrm{f}_{\mathrm{p} .1}(\mathrm{p}, \mathrm{t}) \cdot \sqrt{\frac{2 \cdot\left|\mathrm{p}_{\mathrm{j}-1}-\mathrm{p}_{\mathrm{j}}\right|}{\rho}} \cdot \operatorname{sign}\left(\mathrm{p}_{\mathrm{j}-1}-\mathrm{p}_{\mathrm{j}}\right) ; \\
& \mathrm{Q}_{\mathrm{p} .2}^{\mathrm{i}}=\mu_{\mathrm{p} .2}^{\mathrm{i}} \cdot \mathrm{f}_{\mathrm{p} .2}(\mathrm{p}, \mathrm{t}) \cdot \sqrt{\frac{2 \cdot\left|\mathrm{p}_{\mathrm{j}-1}-\mathrm{p}_{\mathrm{j}}\right|}{\rho}} \cdot \operatorname{sign}\left(\mathrm{p}_{\mathrm{j}-1}-\mathrm{p}_{\mathrm{j}}\right),
\end{aligned}
$$

де $\mathrm{Q}_{\mathrm{p} .1}^{\mathrm{i}} \mathrm{i} \mu_{\mathrm{p} .1}^{\mathrm{i}}, \mathrm{Q}_{\mathrm{p} .2}^{\mathrm{i}} \mathrm{i} \mu_{\mathrm{p} .2}^{\mathrm{i}}-$ величина і коефіцієнт витрати крізь відповідний керуючий пристрій; $\mathrm{f}_{\mathrm{p} .1}(\mathrm{p}, \mathrm{t})$ i $\mathrm{f}_{\mathrm{p} .2}(\mathrm{p}, \mathrm{t})$-площі прохідних перетинів відповідних пристроїв у функції тиску та часу; $\mathrm{p}_{\mathrm{j}-1} \mathrm{i} \mathrm{p}_{\mathrm{j}}-$ тиск на кінцевих ділянках відповідних трубопроводів.

Окрім того, граничними умовами для системи рівнянь (2), (4)-(6) є також вираження витрат у відповідних перетинах гідромагістралей [13]:

$$
Q_{i . \Pi}=\alpha_{i . \Pi} \cdot f_{i} \cdot \sqrt{\frac{2 \cdot\left|p_{j-1}-p_{j}\right|}{\rho}} \cdot \operatorname{sign}\left(p_{j-1}-p_{j}\right),
$$

де $\alpha_{i . п}$-коефіцієнт витрати крізь відповідний трубопровід; $\mathrm{f}_{\mathrm{i}}$-площі прохідних перетинів відповідних трубопроводів.

Для адекватного моделювання динамічних явищ в гідросистемі механізму затискання штаби двоконусного розмотувача необхідно враховувати не раптовість спрацьовування керуючих гідророзподільників. Дослідження характеру спрацьовування розподільних пристроїв золотникового типу [14] в умовах об’ємного гідроприводу показали, що як при відкриванні, так і при закриванні керуючого пристрою його прохідний перетин змінюється практично по лінійному закону.

У результаті проведених натурних досліджень $[9,10]$ спрацьовування керуючих гідророзподільників золотникового типу було встановлено, що площі прохідного перетину гідророзподільника змінюється по закону, близькому до лінійного, тобто: 
«Системні технології» 2 (127) 2020 «System technologies»

$\begin{cases}\text { при відкритті } \mathrm{f}_{\mathrm{i}}(\mathrm{p}, \mathrm{t})=\mathrm{f}_{\mathrm{i}}^{\max } \frac{\mathrm{t}}{\mathrm{t}_{\mathrm{o}}} ; \\ \text { при закритті } \mathrm{f}_{\mathrm{i}}(\mathrm{p}, \mathrm{t})=\mathrm{f}_{\mathrm{i}}^{\max }\left(1-\frac{\mathrm{t}}{\mathrm{t}_{3}}\right)\end{cases}$

де $\mathrm{f}_{\mathrm{i}}^{\mathrm{max}}$-максимальна площа прохідного перетину гідророзподільника; $\mathrm{f}_{\mathrm{i}}(\mathrm{p}, \mathrm{t})$-зміна площі прохідного перетину гідророзподільника.

Прийняті значення постійних параметрів гідросистеми наступні: $\mathrm{p}_{\mathrm{H}}=6,3$ МПа; $\quad \mathrm{p}_{\mathrm{a}}=0,1 \mathrm{MПа} ; \quad \mathrm{m}_{1}=\mathrm{m}_{2}=4100 \mathrm{\kappa г} ; \quad \mathrm{F}_{11}=\mathrm{F}_{12}=\mathrm{F}_{21}=$ $=\mathrm{F}_{22}=40,408 \cdot 10^{-3} \mathrm{M}^{2} ; \quad \mathrm{x}_{1}=\mathrm{x}_{2}=0,350 \mathrm{M} ; \quad \mathrm{L}_{1 \mathrm{H}}=\mathrm{L}_{2 \mathrm{H}}=\mathrm{L}_{1 \mathrm{c}}=\mathrm{L}_{2 \mathrm{c}}=20 \mathrm{M} ;$ $\mathrm{k}_{\mathrm{j}}=5 ; \quad \mathrm{f}_{\mathrm{j}}=\mathrm{f}_{1 \mathrm{H}}=\mathrm{f}_{2 \mathrm{H}}=\mathrm{f}_{1 \mathrm{c}}=\mathrm{f}_{2 \mathrm{c}}=19,625 \cdot 10^{-4} \mathrm{M}^{2} ; \quad \mathrm{E}_{\mathrm{p}}=1,6 \cdot 10^{9}$ Па; $\mathrm{E}_{\mathrm{T}}=2,0 \cdot 10^{11}$ Па; $\quad \rho=912 \mathrm{\kappa г} / \mathrm{M}^{3} ; \quad \mathrm{h}=37,89 \cdot 10^{-6} ; \quad \mathrm{T}_{\text {тр.н }}=10,1 \mathrm{\kappa H} ;$ $\mathrm{T}_{\text {тр.уп }}=20 \mathrm{kH} ; \xi_{\mathrm{i}, \mathrm{j}} \cong 7 ; \alpha_{\mathrm{i} . \Pi}=0,35 ; \mu_{\mathrm{p} .1}=\mu_{\mathrm{p} .2}=0,65$.

Повну систему рівнянь (2), (4)-(6) з граничними умовами (7)-(9) зручно реалізувати на ПЕОМ за допомогою стандартних методів РунгеКутта. У ході реалізації системи рівнянь у програмному продукті Simulink MATLAB, були отримані результати дослідження динамічних процесів в гідросистемі механізму затискання штаби. Результати досліджень наведені на рис. 2 для робочого ходу та на рис. 3 для зворотного ходу механізму затискання штаби відповідно.

Порівнюючи отримані результати дослідження режимів роботи гідросистеми механізму затискання штаби двоконусного розмотувача для робочого та зворотного ходів гідроциліндрів видно, що в них відбуваються однакові динамічні процеси як при робочому так и зворотному ході. Це пояснюється тим, що у гідросистемі використовуються два однакові за конструкцією гідроциліндри. Окрім того, робота гідроциліндрів гідравлічно синхронізовано. Тому, при однакових навантаженнях, які діють на гідроциліндри, в них відбуваються однакові перехідні процеси, та режими їх роботи ідентичні. 
«Системні технології» 2 (127) 2020 «System technologies»
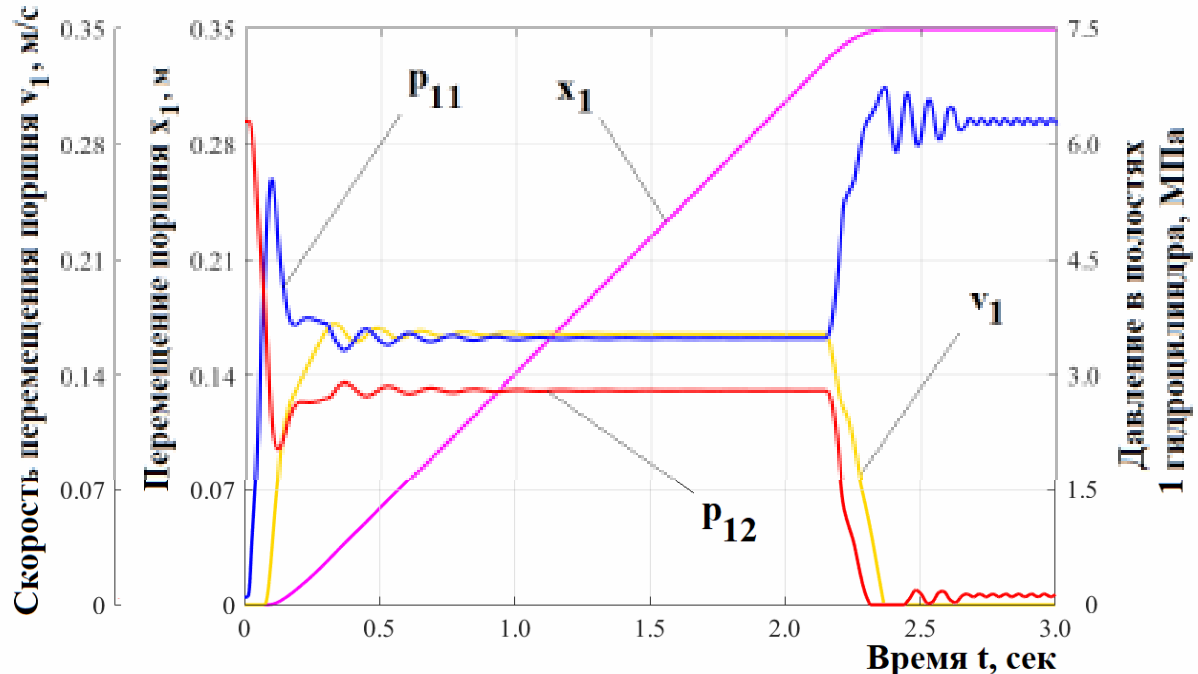

a)
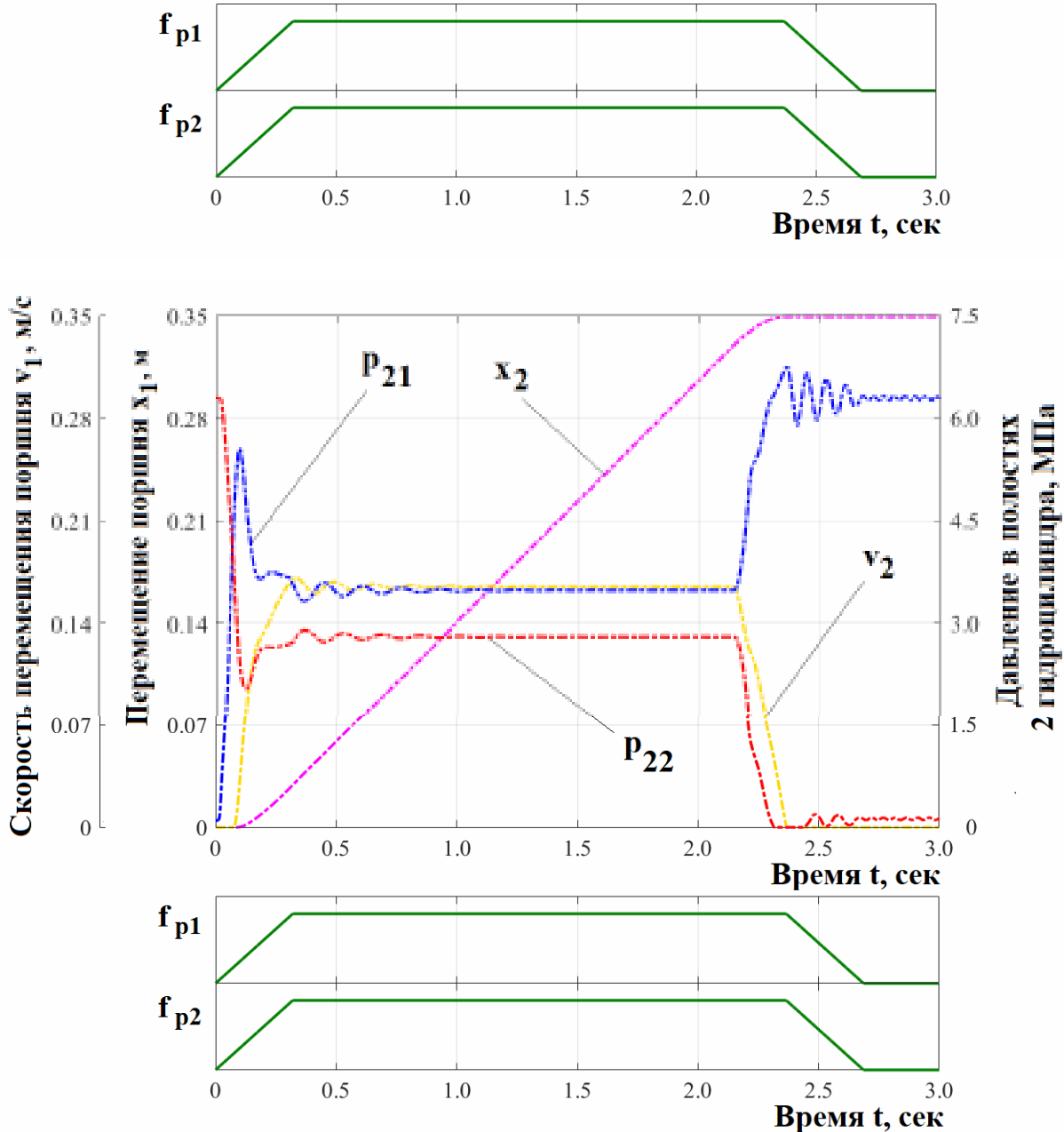

б)

Рисунок 2 - Результати дослідження режимів роботи гідросистеми механізму затискання штаби двоконусного розмотувача при робочому ході лівого (а) та правого (б) гідроциліндру 
«Системні технології» 2 (127) 2020 «System technologies»
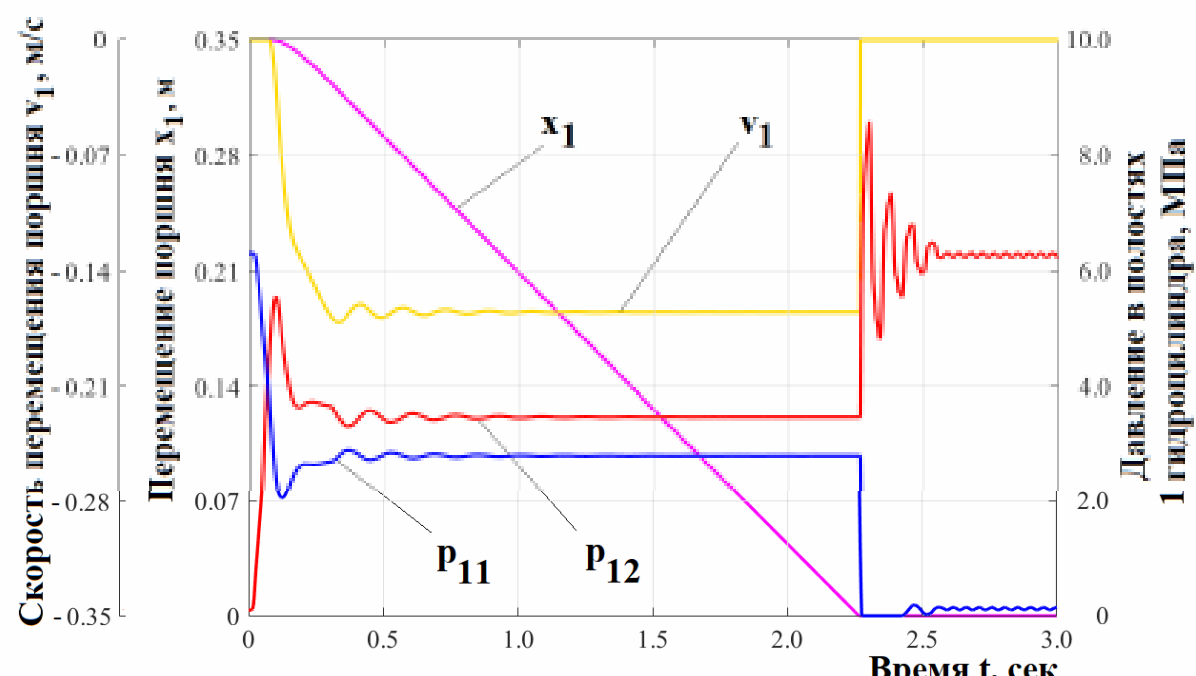

a)
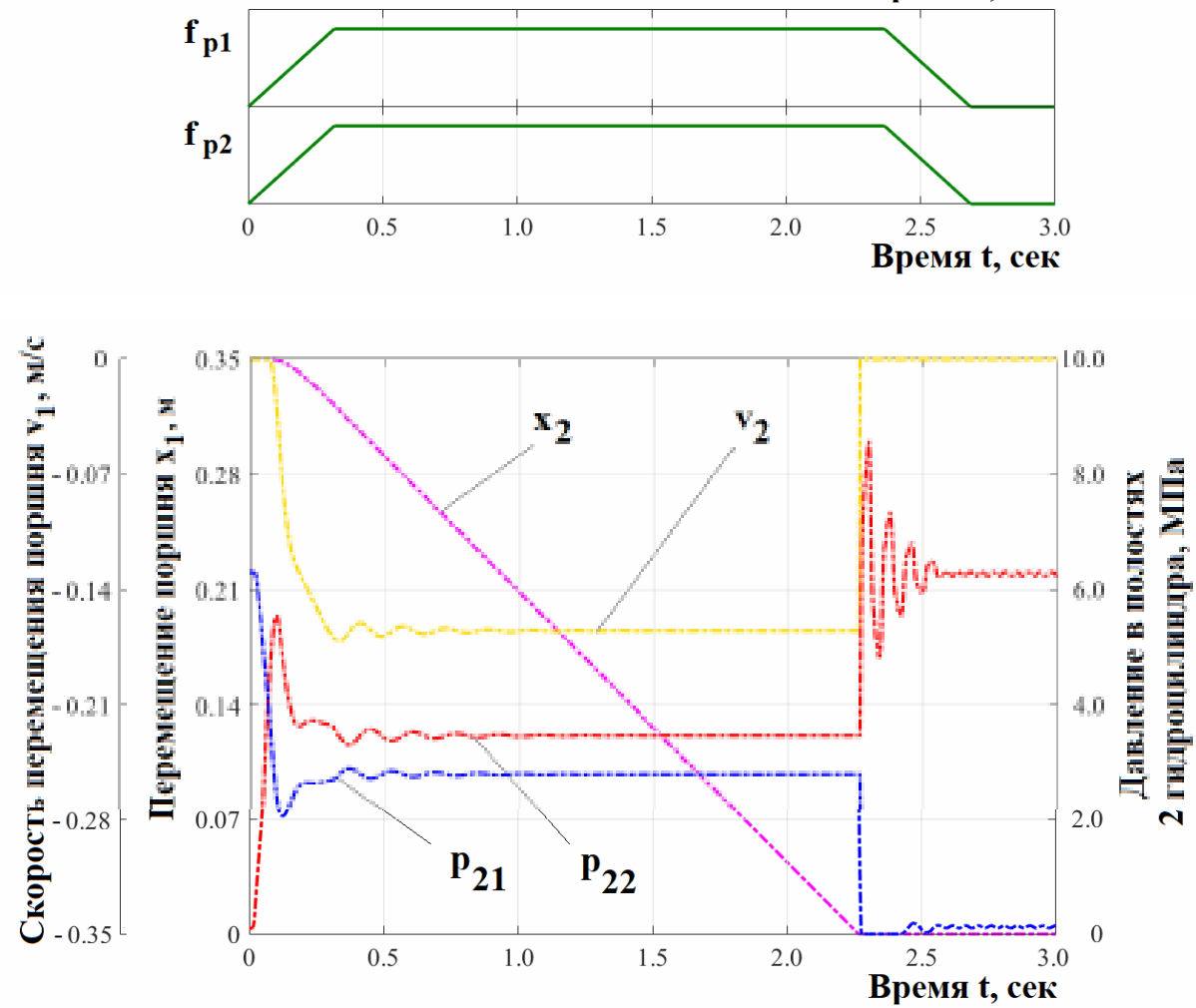

б)

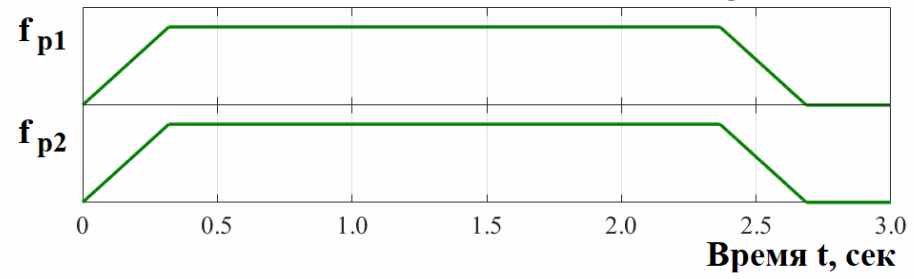

Рисунок 3 - Результати дослідження режимів роботи гідросистеми механізму затискання штаби двоконусного розмотувача при зворотному ході лівого (а) та правого (б) гідроциліндру 
«Системні технології» 2 (127) 2020 «System technologies»

В результаті дослідження гідросистеми механізму затискання штаби двоконусного розмотувача рулонів ТЕЗА 159-529 було встановлено, що при проектному режимі роботи небезпечні динамічні навантаження у самій гідросистемі виникають лише на при кінці зворотного ходу гідроциліндрів. При цьому коефіцієнт динамічності гідросистеми складає $8,6 / 6,3=1,36$, що значно перевищує гранично допустиме значення. Було показано, що при зворотному ході гідроциліндрів механізму у кінцевих положеннях виникає раптова зупинка поршня гідроциліндру на жорсткий упор (кришки гідроциліндра), що призводить до раптового навантаження.

Виходячи з вище сказаного, необхідно визначити раціональні режими роботи гідросистеми механізму затискання штаби двоконусного розмотувача у період гальмування на при кінці зворотного ходу з мінімальними динамічними навантаженями.

Найбільш розповсюдженим варіантом гальмування поршня гідроциліндра з двома керуючими гідророзподільниками, у кінцевих положеннях, є окреме їх закриття та гальмування поршня гідроциліндра веретеном (конічним хвостовиком).

Гальмування поршня гідроциліндра веретеном (конічним хвостовиком) не розглядається тому, що це значно збільшить габаритні розміри гідроциліндра та призведе до зміни конструкції як самої гідросистеми затискання штаби, так і двоконусного розмотувача.

Нами буде розглядатися раціональний порядок закриття керуючих золотникових гідророзподільників. Питання збільшення часу закриття та збільшення чи зменшення площі прохідного перетину золотникового гідророзподільника розглядатися не буде тому, що це призведе до зміни як конструктивних так і технологічних параметрів механізму затискання штаби. Задача полягає у тому, щоб рекомендувати такий раціональний порядок роботи існуючих золотникових гідророзподільників, при якому динамічні навантаження у гідросистемі були б найменшими.

Результати дослідження динамічних процесів, що відбуваються в гідросистемі механізму затискання штаби двоконусного розмотувача у період гальмування гідроциліндрів при зворотному ході з різними варіа36 
«Системні технології» 2 (127) 2020 «System technologies»

нтами спрацьовуванням керуючих гідророзподільників, представлені на рис. 4.

На рис. 4а представлені результати дослідження при одночасному спрацьовуванню двох гідророзподільників за 0,32 сек при переміщені поршня на довжину 0,35 м. При цьому, тиск рідини у правій порожнині гідроциліндру підвищиться до 8,6 МПа, а у лівій порожнині знизиться до 0. Швидкість переміщення раптово знизиться від значення сталого руху до 0. У продовж наступних 0,32 сек відбувається закриття гідророзподільників, одночасно з цим у порожнинах гідроциліндра відбуваються перехідні процеси у відповідних порожнинах, які до повного закриття гідророзподільника затухають. При цьому тиск у правій порожнині встановлюється на рівні 6,3 МПа, а у лівій - на рівні 0,1 МПа після повного закриття обох гідророзподільників.

На рис. 46 представлені результати дослідження при одночасному спрацьовуванню двох гідророзподільників за 0,16 сек при досягненні переміщення поршня на довжину 0,35 м. Отримані результати ідентичні результатам за час спрацьовування гідророзподільників за 0,32 (рис. 3а). Відмінність отриманих результатів полягає у скороченні коливального процесу у порожнинах гідроциліндрів при переміщенні поршня на 0,35 м. Це пов’язано зі скороченням часу спрацьовування розподільників.

На рис. 4в представлені результати дослідження при початку закриття 1 гідророзподільника у період, коли поршень переміститься на довжину 0,3 м та початку закриття 2 гідророзподільника при переміщенні поршня на довжину 0,35 м з часом спрацьовування 0,16 сек. Отримані результати свідчать проте, що при такому порядку спрацьовування гідророзподільників у гідросистемі спостерігаються значні перехідні процеси. Це пояснюється тим, що 1 гідророзподільник починає закриватися при переміщенні поршня на довжину 0,3 м, тиск у лівій порожнині гідроциліндра збільшується, а у провій порожнині зменшується за рахунок збільшення опору на гідророзподільниках, що призводить до збудження коливальних процесів в порожнинах гідроциліндру. 
«Системні технології» 2 (127) 2020 «System technologies»
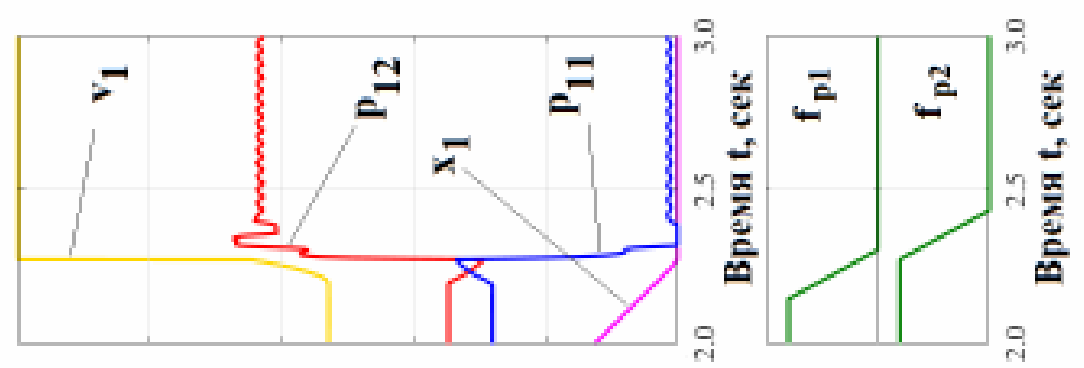

.
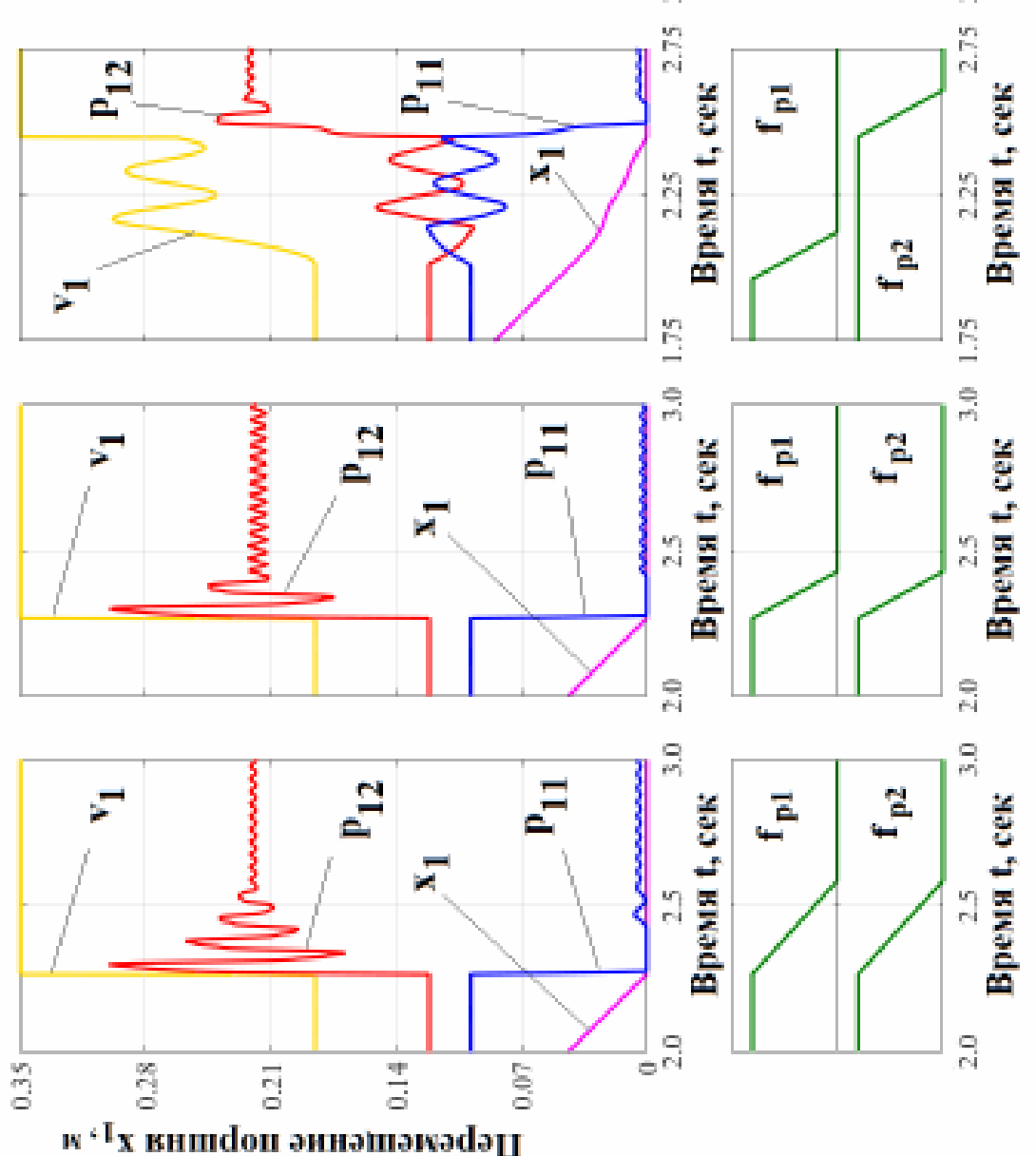

๓
6
ฮ

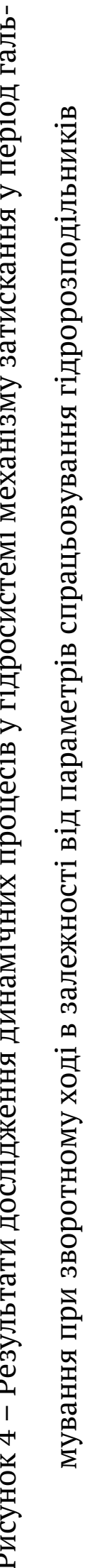


«Системні технології» 2 (127) 2020 «System technologies»

На рис. 4г представлені результати дослідження при початку закриття 1 гідророзподільника у період, коли поршень переміститься на довжину 0,33 м та початку закриття 2 гідророзподільника при переміщенні поршня на довжину 0,35 м, з часом спрацьовування 0,16. При такому порядку закриття гідророзподільників тиск в правій порожнині гідроциліндру спочатку падає а лівій порожнині збільшується, що пов’язано зі збільшенням опору гідророзподільниках. Швидкість переміщення, при цьому починає падати. При досягненні поршня переміщення у 0,35 м, 1 гідророзподільник майже повністю закритий при цьому починає закриватися 2 гідророзподільник. Тиск у лівій порожнині падає до нуля, а у правій порожнині збільшується 6,5 МПа. Це пов’язано з дією сили, яка зупиняє переміщення поршня. За час закриття 2 гідророзподільника тиск у правій порожнині знижується до 6,3МПа, а у правій порожнині збільшується до 0,1 МПа.

У результаті досліджень показано, що найбільш доцільний є варіант окремого включення гідророзподільників з закриттям 1 гідророзподільника при переміщенні поршня на довжину 0,33 м, а 2 гідророзподільника при переміщенні поршня на довжину 0,35 м. При такому режимі роботи гідророзподільників динамічні навантаження у гідросистемі будуть мінімальними.

Висновки. За результатами теоретичних досліджень гідросистеми механізму затискання штаби двоконусного розмотувача при зворотному ході можливо рекомендувати наступні заходи з удосконалення гідросистеми. По-перше замість застарілих золотникових гідророзподільників 3 часом спрацьовування у 0,32 сек застосувати золотникові гідророзподільники, які мають час спрацьовування 0,16 сек. По-друге, змінити порядок спрацьовування нових гідророзподільників з електрогідравлічним керуванням наступним чином: на початку зворотного ходу гідроциліндра починає відкривається 1 гідророзподільник а 2 гідророзподільник починає відкриватися через 0,1 сек після початку відкриття 1 гідророзподільника; на при кінці зворотного ходу 1 гідророзподільник починає закриватися при переміщенні поршня на 0,33 м, а 2 гідророзподільник починає закриватися при переміщенні поршня на 0,35 м. 
«Системні технології» 2 (127) 2020 «System technologies»

\section{ЛІТЕРАТУРА / ЛИТЕРАТУРА}

1. Гликман Б.Ф. Математические модели пневмогидравлических систем / Б.Ф.Гликман- М.: Наука, 1986. - 368 с.

2. Жуковский H.Е. О гидравлическом ударе в водопроводных трубах / Н.Е. Жуковский - М.: Л.: Гостехиздат, 1949. - 412 с.

3. Тарко Л.М. Переходные процессы в гидравлических механизмах / Л.М. Тарко. - М.: Машиностроение, 1973. - 163 с.

4. Кожевников С.Н. Электронное моделирование гидравлических устройств с учетом волновых процессов в трубопроводе / С.Н. Кожевников, В.Ф. Пешат, В.М. Лобода // Гидропривод и гидропневмоавтоматика: Респ. межвед. научн.-техн. сб. - 1986. - вып. 22. - С. 117-123.

5. Немировский И.А. О реальном построении математической модели при исследовании волновых процессов в трубопроводе / И.А. Немировский, Ж.П. Дусанюк, В.А. Черный // Гидропривод и гидропневмоавтоматика: Респ. межвед. научн.-техн. сб. - 1986. - вып. 22. - С. 60-64.

6. Дусанюк Ж.П. Математична модель для імітаційного дослідження в середовищі MATLAB Simulink гідравлічного приводу поступального руху 3 довгою напірною гідролінією / Ж.П. Дусанюк, О.В. Дерібо, С.В. Репінський [та ін.] // Вісник Вінницького політехнічного інституту. - 2016. № 3. - С. 108-115.

7. Дусанюк Ж.П. Математична модель та алгоритм дослідження динаміки гідроприводу ковша неповноповоротного екскаватора з урахуванням хвильових процесів в напірній гідролінії / Ж.П. Дусанюк, О.В. Петров, О.В. Дерібо [та ін.] // Вісник Вінницького політехнічного інституту. 2015. - № 3. - C. 121-128.

8. Дерібо О.В. Імітаційне дослідження гідравлічного приводу поступального руху з довгою напірною гідролінією / О.В. Дерібо, Ж.П. Дусанюк, С.В. Репінський [та ін.] // Вісник Вінницького політехнічного інституту. 2017. - № 1. - С. 85-92.

9. Исследование методами математического моделирования гидромеханических систем быстроходных гидропрессов для производства колес и колец с целью выбора рациональных технологических режимов: Отчет о 
«Системні технології» 2 (127) 2020 «System technologies»

НИР / Институт черной металлургии; Руководитель А.М.Иоффе. - №ГР 01860017042. - Днепропетровск, 1987. - 73 с.

10. Иоффе А.М. Определение динамических нагрузок в гидросистемах металлургических агрегатов при помощи математического моделирования / А.М. Иоффе, О.Н. Кукушкин, К.П. Лопатенко, Н.В. Михайловский М.: Металлургия, 1986. - 32 с.

11. Мазур И.А. Совершенствование гидромеханических систем специальных машин колесопрокатного производства: Дис. ... канд. техн. наук: 05.05.08. / Мазур Игорь Анатольевич. - Днепропетровск, 2003. - 190 с.

12. Тарко Л.М. Динамический анализ замкнутой гидропередачи / Тарко Л.М. // Пневматика и гидравлика: Приводы и системы управления. - 1986. - вып. 12. - С. 80 - 87.

13. Кожевников С.Н. Гидравлический и пневматический приводы металлургических машин / С.Н. Кожевников, В.Ф. Пешат. - М.: Машиностроение, 1973. - 360 с.

14. Kinoglu F. Analyzing hudraulic system through computer integration / F. Kinoglu, D.Riley, M. Donath // Hydraulics and pneumatics. - 1985. - V. 38. - n. 11. - pp. 88 - 90, 92, 112 .

\section{REFERENCES}

1. Glikman B.F. Matematicheskie modeli pnevmogidravlicheskih sistem / B.F.Glikman- M.: Nauka, 1986. - 368 p.

2. Zhukovskiy N.E. O gidravlicheskom udare v vodoprovodnyih trubah / N.E. Zhukovskiy - M.: L.: Gostehizdat, 1949. - 412 p.

3. Tarko L. M. Perehodnyie protsessyi v gidravlicheskih mehanizmah / L.M. Tarko. - M.: Mashinostroenie, 1973. - 163 p.

4. Kozhevnikov S.N. Elektronnoe modelirovanie gidravlicheskih ustroystv s uchetom volnovyih protsessov v truboprovode / S.N. Kozhevnikov, V.F. Peshat, V.M. Loboda // Gidroprivod i gidropnevmoavtomatika: Resp. mezhved. nauchn.-tehn. sb. - 1986. - V. 22. - P. 117-123.

5. Nemirovskiy I.A. O realnom postroenii matematicheskoy modeli pri issledovanii volnovyih protsessov v truboprovode / I.A. Nemirovskiy, Zh.P. Dusanyuk, V.A. Chernyiy // Gidroprivod i gidropnevmoavtomatika: Resp. mezhved. nauchn.-tehn. sb. - 1986. - V. 22. - P. 60-64. 
«Системні технології» 2 (127) 2020 «System technologies»

6. Dusaniuk Zh.P. Matematychna model dlia imitatsiinoho doslidzhennia v seredovyshchi MATLAB Simulink hidravlichnoho pryvodu postupalnoho rukhu z dovhoiu napirnoiu hidroliniieiu / Zh.P. Dusaniuk, O.V. Deribo, S.V. Repinskyi [ta in.] // Visnyk Vinnytskoho politekhnichnoho instytutu. - 2016. - № 3. - P. 108-115.

7. Dusaniuk Zh.P. Matematychna model ta alhorytm doslidzhennia dynamiky hidropryvodu kovsha nepovnopovorotnoho ekskavatora $\mathrm{z}$ urakhuvanniam khvylovykh protsesiv v napirnii hidrolinii / Zh.P. Dusaniuk, O.V. Petrov, O.V. Deribo [ta in.] // Visnyk Vinnytskoho politekhnichnoho instytutu. - 2015. № 3. - P. 121-128.

8. Deribo O.V. Imitatsiine doslidzhennia hidravlichnoho pryvodu postupalnoho rukhu z dovhoiu napirnoiu hidroliniieiu / O.V. Deribo, Zh.P. Dusaniuk, S.V. Repinskyi [ta in.] // Visnyk Vinnytskoho politekhnichnoho instytutu. - 2017. - № 1. - P. 85-92.

9. Issledovanie metodami matematicheskogo modelirovaniya gidromehanicheskih sistem byistrohodnyih gidropressov dlya proizvodstva koles i kolets $\mathrm{s}$ tselyu vyibora ratsionalnyih tehnologicheskih rezhimov: Otchet o NIR / Institut chernoy metallurgii; Rukovoditel A.M. Ioffe. - №GR 01860017042. - Dnepropetrovsk, 1987. - 73 p.

10. Ioffe A.M. Opredelenie dinamicheskih nagruzok $\mathrm{v}$ gidrosistemah metallurgicheskih agregatov pri pomoschi matematicheskogo modelirovaniya / A.M. Ioffe, O.N. Kukushkin, K.P. Lopatenko, N.V. Mihaylovskiy - M.: Metallurgiya, 1986. - $32 \mathrm{p}$.

11. Mazur I.A. Sovershenstvovanie gidromehanicheskih sistem spetsialnyih mashin kolesoprokatnogo proizvodstva: Dis. ... kand. tehn. nauk: 05.05.08. / Mazur Igor Anatolevich. - Dnepropetrovsk, 2003. - 190 p.

12. Tarko L.M. Dinamicheskiy analiz zamknutoy gidroperedachi / Tarko L.M. // Pnevmatika i gidravlika: Privodyi i sistemyi upravleniya. - 1986. - V. 12. P. $80-87$.

13. Kozhevnikov S.N. Gidravlicheskiy i pnevmaticheskiy privodyi metallurgicheskih mashin / S.N. Kozhevnikov, V.F. Peshat. - M.: Mashinostroenie, 1973. - $360 \mathrm{p}$. 
«Системні технології» 2 (127) 2020 «System technologies»

14. Kinoglu F. Analyzing hudraulic system through computer integration

/ F. Kinoglu, D.Riley, M. Donath // Hydraulics and pneumatics. - 1985. - V. 38.

- n. 11. - pp. 88 - 90, 92, 112.

Received 03.02.2020.

Accepted 07.02.2020.

\section{Исследование динамических процессов в гидросистеме зажима рулона двухконусного} разматывателя рулонов ТЕЗА 159-529

Аннотация. Работа посвящена исследованию динамических нагрузок, возникающих в гидросистеме механизма зажима рулона двухконусного разматывателя рулонов ТЕЗА 159-529. Опыт эксплуатации двухконусного разматывателя показал, что одним из его недостатков является неудовлетворительная работа гидросистемы зажима рулона, в которой наблюдаются повышенные динамические нагрузки. В гидросистеме механизма зажима рулона исполнительный гидроцилиндр расположен на большом расстоянии от источника давления, поэтому в ней используются длинные гидромагистрали. В переходных режимах работы машины с такой гидросистемой, в ней возникают волновые процессы (нестационарное движение жидкости), которые влияют на качество ее функционирования.

На основании анализа математических моделей, применяемых в практике динамических расчетов реальных гидросистем показано, что в качестве математической модели, которая учитывает особенности конструкции и работы гидросистемы механизма зажима рулона двухконусного разматывателя, целесообразно использовать систему дифференциальных уравнений в частных производных, преобразованных конечно-разностным методом в систему обыкновенных дифференциальных уравнений с граничными условиями. Это дает возможность создания динамической модели, которая позволяет с высокой достоверностью анализировать поведение гидросистемы механизма зажима рулона двухконусного разматывателя. В ходе реализации предложенной математической модели в программной среде Simulink MATLAB выполнено исследование режимов работы гидросистемы механизма зажима рулоны. В результате исследования показано, что в гидросистеме механизма зажима рулона двухконусного разматывателя возникают динамические нагрузки в конце возвратного хода которые значительно превышают допустимые значения.

C целью снижения динамических нагрузок, предложен порядок работы гидрораспределителей с временем срабатывания 0,16 сек. Это позволяет существенно снизить динамические нагрузки в гидросистеме механизма зажима рулона за счет снижения скорости перемещения гидроцилиндров в конце обратного хода каретки.

Ключевые слова: разматыватель двухконусный, гидросистема, давление, усилия, гидрораспределитель, время срабатывания, нагрузки динамические, процессы переходные.

The study of dynamic processes in the hydraulic system of the roll clamp of a two-cone unwinder rolls pipe-welding unit 159-529

Abstract. The work is devoted to the study of dynamic loads arising in the hydraulic system of the clamping mechanism of a roll of a two-cone unwinder of rolls of tubes of a pipe-welding unit 159-529. The operating experience of the two-cone unwinder has shown that one of its drawbacks is the unsatisfactory operation of the roll clamp hydraulic system, in which increased 


\section{«Системні технології» 2 (127) 2020 «System technologies»}

dynamic loads are observed. In the hydraulic system of the roll clamping mechanism, the executive hydraulic cylinder is located at a large distance from the pressure source, therefore, it uses long hydraulic lines. In transient modes of operation of a machine with such a hydraulic system, wave processes arise in it (unsteady fluid motion), which affect the quality of its functioning.

Based on the analysis of mathematical models used in the practice of dynamic calculations of real hydraulic systems, it is shown that it is advisable to use a system of partial differential equations converted by a finite-difference method into a system as a mathematical model that takes into account the design and operation of the hydraulic system of the roll clamp mechanism of a two-cone unwinder ordinary differential equations with boundary conditions. This makes it possible to create a dynamic model that allows with high reliability to analyze the behavior of the hydraulic system of the mechanism of the clamping roll of a two-cone unwinder. During the implementation of the proposed mathematical model in the Simulink MATLAB software environment, a study was made of the operating modes of the hydraulic system of the roll clamping mechanism. As a result of the study, it was shown that in the hydraulic system of the roll clamping mechanism of a two-cone unwinder, dynamic loads occur at the end of the return stroke, which significantly exceed the permissible values.

In order to reduce dynamic loads, a valve operating procedure with a response time of 0.16 seconds is proposed. This allows you to significantly reduce dynamic loads in the hydraulic system of the roll clamping mechanism by reducing the speed of movement of the hydraulic cylinders at the end of the carriage return stroke.

Keywords: double-cone unwinder, hydraulic system, pressure, effort, hydraulic distributor, time of operation, dynamic loading, transient processes.

Мазур Игорь Анатольевич - к.т.н., доцент, Национальная металлургическая академия Украины.

Шелудько Дмитрий Олегович - аспірант, Национальная металлургическая академия Украины.

Петров Михаил Иванович - студент, Национальная металлургическая академия Украины.

Мазур Ігор Анатолійович - к.т.н., доцент, Національна металургійна академія України.

Шелудько Дмитро Олегович - аспірант, Національна металургійна академія України.

Петров Михайло Іванович - студент, Національна металургійна академія України.

Mazur Igor - candidate of technical sciences, associate professor, National Metallurgical Academy of Ukraine.

Sheludko Dmitry - graduate student, National Metallurgical Academy of Ukraine.

Petrov Mykhailo - student, National Metallurgical Academy of Ukraine. 